\title{
EDUCAÇÃO PARA A SAƯdE EM UM AMBULATÓRIO DE PEDIATRIA
}

Maria do Carmo Marcondes Pincherle*

PINCHERLE, $M$.do C. $M$. Educação para a saúde em um ambulatório de pediatria. Rev. Esc. Enf. USP, São Paulo, 16(1):85-88, 1982.

A Autora relata sua experiência como enfermeira voluntária em um ambulatório de Pediatria pertencente a uma entidade assistencial privada sem fins lucrativos. Descreve o programa de educação das mães sobre a introdução da soja na alimentação. Refere também a instituição de um serviço de empréstimo para a compra de medicamentos.

\section{INTRODUÇÃO}

Segundo já foi relatado em trabalho anterior (PINCHERLE, 1980) ** a Assistência Social Santo Antonio (ASSA) é uma entidade privada sem fins lucrativos, que mantém um ambulatório ligado ao Centro de Saúde da Associação Hospital de Cotia.

A enfermeira voluntária, num plantão de quatro horas uma vez por semana, faz palestras de puericultura às mães e dá orientação após a consulta médica, atendendo à média de 90 mães por mês.

Para melhorar o nivel de atendimento foram criadas duas novas atividades neste ambulatório, abaixo descritas.

\section{INTRODUÇÃO DA SOJA NA ALIMENTAÇÃO}

O maior problema das crianças pobres brasileiras é a fome, que segundo nossa observação vem aumentando assustadoramente ano em ano. O poder aquisitivo das famílias é cada vez menor e as condiçōes da alimentação cada vez mais precárias.

Sendo a soja uma das melhores fontes de proteína, como pode ser visto na tabela abaixo, a autora resolveu iniciar um programa de orien. tação às mães sobre a introdução da soja na alimentação.

* Enfermeira voluntária.

** PINCHERLE, M. do C. M. Educação sanitária em ambulatório de pediatria. Rov. Eac. Enf. USP, Săo Paulo, 14(3):271-3, dez. 1980. 
Valor protéico da soja em comparação com as demais fontes de proteina.

Alimentos Proteinas (100 g) Carbohidratos (100 g) Gorduras (100 g)

\begin{tabular}{lrcr}
\hline carne & 20,50 & - & 6,50 \\
leite & 3,50 & 4,50 & 3,50 \\
ovos & 12,50 & - & 11,30 \\
soja & 39,40 & 10,50 & 21,80 \\
\hline
\end{tabular}

A soja custa, aproximadamente, seis vezes menos que o feijão e dez vezes menos que a carne mais barata.

O programa constou de campanha intensiva para introduzir a soja na alimentação. Durante oito semanas, a autora fez palestras só sobre alimentação e soja. Nas palestras foi ensinado o valor da soja e distribuidos folhetos com as receitas dos alimentos à base de soja (folhetos obtidos na Secretaria de Agricultura e Abastecimento). A autora preparou, em sua própria casa, os alimentos à base de soja, tais como, sopa de abóbora com leite de soja, farinha de soja, pudim de leite de soja com chocolate, leite de soja quente com chocolate, "sojão" preparado como feijão, arroz enriquecido com soja e legumes, e os trouxe ao ambulatório para que as mães experimentassem.

$O$ interesse que despertou foi surpreendente. A maioria nunca tinha ouvido falar em soja, mas provou, gostou e se interessou em levar as receitas para casa.

Foi anotada, na ficha de cada criança, se a mãe havia provado os alimentos e se levara as receitas para casa, para que nas próximas consultas pudesse ser pesquisado se tinha havido interesse no uso da soja.

Durante a campanha, de oito semanas, 150 mães experimentaram algum prato à base de soja. Só uma minoria não se interessou (5\% das mães não quiseram nem provar a soja).

Este trabalho de nutrição feito no ambulatório foi o único possivel dentro dos recursos disponíveis. $\mathrm{E}$ claro que o ideal seria que o ambulatório contasse com uma cozinha, uma dietista e proporcionasse cursos regulares, dados às mães, para estas aprenderem a fazer pratos à base de soja, além de sopinhas, mamadeiras e toda a alimentação infantil.

Foi solicitado às mães que divulgassem o que haviam aprendido junto aos membros de sua familia, as suas amigas e vizinhas e que fornecessem as receitas recebidas. A autora continuou a fornecer regularmente, às clientes do ambulatório, as receitas à base de soja.

Se a soja for realmente introduzida na alimentação das famílias brasileiras, virá atenuar a fome e corrigir a deficiência protéica na ali- 
mentação do nosso povo, deficiência esta que nos primeiros anos de vida refletirá no desenvolvimento mental das crianças e que é responsável pelo baixo rendimento escolar dos alunos na escola.

A mudança de hábitos alimentares de um povo é um trabalho árduo e nunca se colhem resultados a curto prazo.

\section{CAIXA DE EMPRÉSTIMOS ÀS FAMfLIAS}

O ambulatório recebe, do Hospital de Cotia, amostras de remédios enviados pela Secretaria de Estado da Saúde e os médicos amigos enviam amostras de seus consultórios particulares mas, assim memo, são insuficientes para suprir a enorme necessidade das famílias carentes que freqüentam o ambulatório. Após a consulta, a autora procura conhecer a possibilidade da família de comprar os medicamentos. Se esta não os pode comprar e se não há amostras a serem distribuídas, a cliente é encaminhada ao Serviço Social do ambulatório. Acontece, porém, que algumas vezes a mãe afirma poder comprar o medicamento, mas só quando ela ou o marido receber o ordenado, o que poderá ser só no fím do mês. Como a doença da criança vem sem escolher o dia do mês a autora faz triagem dos medicamentos receitados. Se se tratar de vermifugo, vitamina ou um medicamento contra anemia, por exemplo, a mãe vai poder esperar que a família receba o ordenado; mas, se for caso de medicação de urgência, como anti-térmico, anti-diarrêico, um remédio para crise de asma etc. ela não poderá esperar; para estes casos, a autora criou uma "Caixa de Empréstimos". O dinheiro emprestado por esta Caixa deverá ser devolvido quando a família puder fazê-lo. Para fazer este empréstimo a autora explica que, se a mãe não pagar, cla não obterá noves empréstimos e nem as outras famílias carentes.

Esta experiência já foi feita em outros ambulatórios pela autora com bons resultados. A maioria das familias paga as dividas corretamente.

\section{AVALIAÇĀO DO TRABALHO DE EDUCAÇÃO PARA A SAÚdE}

\section{Freqüiência às consultas}

Tem-se conseguido freqüência mais regular às consultas médicas. As faltas ao ambulatório cairam de 40 para $20 \%$, em mais ou menos três anos de esforço para tornar as mães mais assíduas.

\section{Maior conscientização das mães pelos problemas dos filhos}

Conseguiu-se, com a educação, que as mães se tornem mais conscientes dos problemas relativos à saúde dos filhos. Por exemplo: quando se perguntava a uma das mães, cujo filho tivesse anemia e a quem fora receitado sulfato ferroso, se ela havia seguido as prescrições médicas ela respondia: "ele tomou um pouco do remédio que estava escrito 
no papel que o médico me deu, mas não sei qual é". Hoje, após receber esclarecimentos sobre a doença, os medicamentos e a importância da alimentação, ela responde: "O médico falou que meu filho sarou da anemia porque tomou ferro e eu procurei melhorar a alimentação dele. Ele está bem de saúde e estou muito contente."

O ambulatório da ASSA atende a $80 \%$ das crianças da região, mas só até dois anos de idade, com consultas regulares, e as demais quando estão doentes.

O ambulatório tem muitas dificuldades como falta de espaço, de material, de pessoal etc.; estas são parcialmente superadas pelo esforço e boa vontade das pessoas que nele trabalham. O desvelo dos médicos, enfermeiras sanitaristas, religiosas e funcionárias supre, em grande parte, as deficiências.

Espera-se, que, em futuro não muito distante, o ambulatório possa contar com mais assistência médica, para atender a todas as crianças da região, e que estas tenham seguimento durante toda a infância e compareçam regularmente às consultas.

E meta, desta equipe, melhorar as condições de saúde das crianças e das familias.

PINCHERLE, M. do C. M. Health education in a Pediatric Out-Patient Clinic. Rev. Esc. Enf. USP, São Paulo, 16(1):85-88, 1982.

The Author reports some of her activities as a volunteer nurse in a Pediatric Out-Patient Clinic operated by a non profit private institution. She describes the health education program for mothers on the introduction of soy bean in the menu. She also tells about the organization of a cash fund from which patients can borrow money to buy medication. 